\title{
A comparison of the exhaust emission of a vehicle fuelled with different ethanol-petrol blends
}

\begin{abstract}
Due to limited fossil fuel resources and a need to reduce anthropogenic $\mathrm{CO}_{2}$ emissions, biofuel usage is increasing in multiple markets. Ethanol produced from the fermentation of biomass has been of interest as a potential partial replacement for petroleum for some time; for spark-ignition engines, bioethanol is the alternative fuel which is currently of greatest interest. At present, the international market for ethanol fuel consists of E85 fuel (with 85 percent ethanol content), as well as lower concentrations of ethanol in petrol for use in standard vehicles (e.g. E5, E10). The potential for reduced exhaust emissions, improved security of fuel supply and more sustainable fuel production makes work on the production and usage of ethanol and its blends an increasingly important research topic. This paper evaluates the possibility of using petrol-ethanol blends in a modern Euro 5 vehicle without substantial engine modification. The influence of different quantities of ethanol in ethanol-petrol blends (E5, E10, E25, E50 and E85) on the emission measurement of the gaseous pollutants carbon monoxide (CO), hydrocarbons $(\mathrm{HC})$, oxides of nitrogen $\left(\mathrm{NO}_{x}\right)$ and carbon dioxide $\left(\mathrm{CO}_{2}\right)$ for a passenger car were analysed over the New European Driving Cycle (NEDC) on a chassis dynamometer. The results obtained revealed that exhaust emissions are affected by the proportion of ethanol in the blend. The air:fuel ratio ( $\lambda)$ and exhaust temperature also varied. Increased fuel consumption was found to broadly correlate with blend energetic content for all blends. The experimental work presented in this paper was performed at BOSMAL Automotive Research and Development Institute as part of a test program evaluating biofuels' influence on light-duty petrol engines for passenger cars and light commercial vehicles.
\end{abstract}

Key words: alternative fuels, ethanol, emission, SI engines

\section{Analiza porównawcza emisji związków szkodliwych spalin samochodu zasilanego różnymi mieszankami benzyny $z$ etanolem}

\begin{abstract}
Ze względu na ograniczone zasoby paliw kopalnych oraz potrzebę zmniejszenia antropogenicznej emisji CO $_{2}$, zużycie biopaliw rośnie na wielu rynkach paliwowych. Od pewnego czasu wzrasta zainteresowanie etanolem otrzymywanym przez fermentację biomasy, jako potencjalnego paliwa mogacego częściowo zastapić benzynę w silnikach o zapłonie iskrowym. Obecnie na międzynarodowym rynku paliw dostępne sq mieszanki benzyny z etanolem E85 (z 85\% etanolu), a także z niższymi stężeniami (np. E5, E10), które są powszechnie stosowane do napędu standardowych pojazdów. Potencjat redukcji emisji związków szkodliwych spalin, zwiększenie bezpieczeństwa dostaw paliw i zrównoważona produkcja paliw sprawiaja, że prace nad metodami produkcji i wykorzystaniem etanolu oraz jego mieszanin staja się coraz ważniejszym kierunkiem badań. Niniejszy artykut analizuje możliwość wykorzystania mieszanek benzyny z etanolem w pojeździe spetniajacym normy emisji Euro 5, bez żadnych modyfikacji silnika oraz oprogramowania (kalibracji) elektronicznej jednostki sterujacej praca silnika (ECU). Ocena wpływu mieszanek paliw, o różnych zawartościach etanolu w benzynie (E5, E10, E25, E50 i E85), na emisję gazowych zanieczyszczeń spalin, takich jak: tlenek węgla (CO), weglowodory $(\mathrm{HC})$, tlenki azotu (NOx) i dwutlenek węgla $\left(\mathrm{CO}_{2}\right)$ z samochodów osobowych zostata wykonana na podstawie Nowego Europejskiego Testu Jezdnego (NEDC) na hamowni podwoziowej. Uzyskane wyniki wskazuja, że udział etanolu w mieszaninie ma wpływ na emisję związów szkodliwych spalin. Wykazano istnienie wpływu różnych mieszanek na zmiane wspótczynnika nadmiaru powietrza ( $\lambda$ i i temperaturę spalin. Dodatkowo stwierdzono zwiększone zużycie paliwa i jego korelację z gęstościa energii zawarta w mieszankach benzyny z etanolem. Badania naukowe przedstawione w niniejszym artykule przeprowadzono w Instytucie Badań i Rozwoju Motoryzacji BOSMAL w ramach programu badań oceny wptywu biopaliw na silniki benzynowe stosowane w lekkich samochodach osobowych i lekkich pojazdach dostawczych.

Słowa kluczowe: paliwa alternatywne, etanol, emisja, silniki ZI
\end{abstract}

\section{Introduction}

\subsection{Bioethanol as an automotive fuel}

Knowledge of the potential usage of ethanol $\left(\mathrm{C}_{2} \mathrm{H}_{6} \mathrm{O}\right)$ as a vehicular fuel dates to the conception of the automobile. Ethanol is the most widely-used biofuel, although its usage is geographically somewhat restricted. Ethanol can be pro-

\section{Wprowadzenie}

\subsection{Bioetanol jako paliwo do napędu pojazdów}

Zainteresowanie wykorzystaniem etanolu $\left(\mathrm{C}_{2} \mathrm{H}_{6} \mathrm{O}\right)$ jako paliwa samochodowego pojawiło się wraz ze skonstruowaniem pierwszych samochodów. Etanol jest najpowszechniej stosowanym biopaliwem, choć jego użycie jest nieco ograni- 
duced using crude oil as a feedstock, but is more commonly sourced from conversion of biomass ('bioethanol'). Since it is derived from biomass (and not fossil hydrocarbons), bioethanol has been identified as a fuel of potential in efforts to make energy consumption in the transportation sector sustainable $[1-3]$. Bioethanol can potentially deliver lifecycle greenhouse gas savings of up to $87 \%$ over fossil fuels [3], although this value can be much lower, as it depends strongly on the feedstock and means of processing and production [3]. Currently, almost all ethanol is produced from the fermentation of edible crops.

Ethanol's properties such as density and octane number make it suitable for combustion in spark-ignition engines, for this application it is normally splash blended with petrol. Blends are identified by an ' $E$ ' followed by the volumetric percentage of ethanol in the blend; E5, E10 and E85 being common blends. The US Environmental Protection Agency (EPA) has granted a waiver for usage of the E15 blend in passenger cars from model years 2001 onwards [4]; blends up to E10 are permitted for sale in the European Union [3]. Ethanol is fully water-miscible and absorbs water; any blend containing ethanol will likely also contain a small proportion of water [2]. Ethanol has a higher density and viscosity than petrol $[5,6]$, is generally more penetrative through physical barriers [7] and has a lower lubricity [8]. One of the distinguishing characteristics of ethanol is that it is an oxygenated fuel, in comparison to petrol, which does not contain appreciable quantities of oxygen. Ethanol can be thought of as a partially oxidized fuel $[9,10]$. The relatively low carbon: hydrogen ratio of ethanol $(0.33)$ means that ethanol blends are an option for reducing $\mathrm{CO}_{2}$ emissions. The addition of even relatively small proportions of ethanol to standard petrol lowers the overall $\mathrm{C}: \mathrm{H}$ ratio of the fuel and makes the resulting blend more attractive.

Ethanol blends are associated with certain issues, including corrosion of various parts of the fuel storage and delivery systems $[11,12,13]$, increased fuel consumption [5 - 7, $14-19]$, possible slight increases in emissions of $\mathrm{NO}_{x}[7$, $18,20]$, and increases in emissions of certain organic compounds [7, 21, 22]. Additionally, conventional aftertreatment systems are not always compatible with usage of ethanol blends. Reduced conversion efficiency and accelerated ageing have both been raised as concerns [4], particularly with higher blends.

\subsection{The effect of petrol-ethanol blends on exhaust emissions}

A large number of studies have indicated that combustion of ethanol and its blends can lead to reduced emissions of $\mathrm{HC}$ and $\mathrm{CO}$, when compared to standard petrol [7, 17, 20]. Such reductions are to be expected, given ethanol's status as an oxygenate, its short chain length and its low $\mathrm{C}: \mathrm{H}$ ratio. However, while ethanol is a partially oxidized fuel, it can be further oxidized without combusting completely, thereby producing aldehydes.

Emissions of $\mathrm{NO}_{x}$ have been reported to increase, decrease or remain unchanged when running on petrol-ethanol blends [7], with a majority of studies reporting a slight czone geograficznie. Etanol może być wytwarzany z surowca, jakim jest ropa naftowa, ale częściej pochodzi z konwersji biomasy ("bioetanol"). Bioetanol pochodzący z biomasy (a nie z kopalnych węglowodorów) jest uznawany za potencjalne paliwo wykorzystywane na rzecz zrównoważonego zużycia energii w sektorze transportowym [1 - 3]. Potencjalnie bioetanol może przyczyniać się do redukcji gazów cieplarnianych nawet o $87 \%$ w porównaniu do paliw tradycyjnych [3], chociaż wartość ta może być znacznie niższa, gdyż silnie zależy od surowca, z jakiego pochodzi bioetanol, sposobu przetwarzania oraz metody produkcji [3]. Obecnie prawie cały etanol jest otrzymywany w wyniku fermentacji produktów roślinnych.

Właściwości etanolu, takie jak gęstość i liczba oktanowa sprawiają, że nadaje się on do spalania w silnikach o zapłonie iskrowym i w tym zastosowaniu stosuje się zazwyczaj mieszanki etanolu z benzyną. Mieszanki są identyfikowane przez oznaczenie literą "E", z następującym dalej oznaczeniem procentowym objętościowej zawartości etanolu w mieszaninie: E5, E10 i E85 (najbardziej popularne oznaczenia). Amerykańska Agencja Ochrony Środowiska (EPA) przyznała ulgi za używanie mieszanek E15 w modelach samochodów osobowych od roku 2001 i późniejszych [4]; natomiast mieszanki do E10 są dopuszczone do sprzedaży na terenie Unii Europejskiej [3]. Etanol jest w pełni mieszalny z wodą i wchłania wodę, dlatego wszelkie mieszanki zawierające etanol będą prawdopodobnie również zawierać niewielkie ilości wody [2]. Etanol ma większą gęstość i lepkość niż benzyna [5, 6], ma większe zdolności przenikania przez bariery fizyczne [7] i gorsze właściwości smarne [8]. Jedną z cech wyróżniających etanol jest to, że jest paliwem utlenionym, w porównaniu do benzyny, która nie zawiera znaczącej ilości tlenu. $Z$ tego względu etanol może być uważany za paliwo już częściowo utlenione [9, 10]. Względnie niska proporcja węgla do wodoru w etanolu $(0,33)$ oznacza, że stosowanie mieszanek etanolu umożliwia redukcję emisji $\mathrm{CO}_{2}$. Ponadto nawet niewielki dodatek etanolu do standardowej benzyny obniża całkowitą proporcję $\mathrm{C}: \mathrm{H}$ w paliwie i sprawia, że otrzymana mieszanka staje się bardziej atrakcyjna w zastosowaniach silnikowych.

Należy wspomnieć o pewnych zagadnieniach odnoszących się do mieszanek etanolu z benzyną, a należą do nich: zwiększona korozja części w układach magazynowania i transportu paliw [11, 12, 13], zwiększone zużycie paliwa przez samochody [5 - 7, $14-19]$, możliwe nieznaczne zwiększenie emisji $\mathrm{NO}_{\mathrm{x}}[7,18,20]$ oraz wzrost emisji niektórych związków organicznych [7, 21, 22]. Ponadto konwencjonalne układy oczyszczania spalin nie zawsze mogą być stosowane z mieszankami etanolu z benzyną. Wykazano, że szczególnie dla mieszanek o większej zawartości etanolu następuje przyspieszone starzenie reaktora katalitycznego (TWC) oraz obniżenie współczynnika redukcji [4].

\subsection{Wpływ mieszanek benzyny z etanolem na emisję związków szkodliwych}

Wiele dotychczasowych badań wykazało, że spalanie etanolu i jego mieszanek prowadzi do zmniejszenia emisji HC i CO, w porównaniu do standardowej benzyny [7, 17, 20]. Takiego obniżenia należy spodziewać się, biorąc pod 
increase [7, $14-18]$, although any excess emissions are generally small [20] and may not be statistically significant in all cases [18]. The addition of oxygenates to petrol generally has a detrimental effect on $\mathrm{NO}_{\mathrm{x}}$ emissions [20]. On the other hand, there are a number of theoretical reasons for pre-catalyst emissions of $\mathrm{NO}_{\mathrm{x}}$ to decrease somewhat with increasing ethanol content [23]. These include more rapid combustion (due to ethanol's faster flame propagation speed, compared to petrol $[6,10,24])$, greater absorption of heat in the cylinder (due to ethanol's higher latent heat of vaporisation, compared to petrol [25]), ethanol's lower flame temperature [26] and the general leaning effect of ethanol's oxygen content [10] (around 34\% higher than standard petrol). In light of these factors, any increases in exhaust emissions of $\mathrm{NO}_{x}$ under normal operating conditions may likely be a result of reduced effectiveness of the aftertreatment system (TWC), due to mixture enleanment.

The low $\mathrm{C}: \mathrm{H}$ ratio of ethanol would suggest a reduction in tailpipe $\mathrm{CO}_{2}$. However, increased combustion efficiency leads to reduced $\mathrm{HC}$ and $\mathrm{CO}$ emissions - but increased $\mathrm{CO}_{2}$ emissions. Additionally, the lower calorific value of ethanol generally requires increased fuelling [5 - 7, $17-19]$, thereby increasing emissions of $\mathrm{CO}_{2}$ somewhat. The overall life-cycle $\mathrm{CO}_{2}$ balance of the fuel depends strongly on the method of production of the ethanol [7, 19].

\section{Methods}

A series of tests was performed with a range of blended fuels on a modern Euro 5, unmodified passenger car. Each blend was the subject of two to three emissions tests. Since currently all petrol fuel sold in Poland contains 5\% ethanol by volume (E5), this blend was used as the base fuel. The experimental work described in this paper was performed in BOSMAL's Euro 5/6 climate-controlled exhaust emissions laboratory equipped with a chassis dynamometer and a windspeed fan, all housed within a climatic chamber (Fig. 1). uwagę status etanolu jako dodatku tlenowego, jego krótką długość łańcucha i niską proporcję C:H. Chociaż etanol jest częściowo utlenionym paliwem, może być dalej utleniany, co w wyniku niecałkowitego spalania skutkować będzie tworzeniem się aldehydów.

W opracowaniach literaturowych wykazano, że emisja $\mathrm{NO}_{\mathrm{x}}$ może wzrastać, spadać lub pozostawać na niezmienionym poziomie podczas zasilania silnika mieszankami benzyny i etanolu [7]. W większości wyników badań uzyskano niewielki wzrost emisji $\mathrm{NO}_{x}[7,14-18]$, chociaż zwiększona emisja jest na ogół niewielka [20] i statystycznie nieistotna we wszystkich przypadkach [18]. Dodatek związków tlenowych do paliwa ma generalnie niekorzystny wpływ na emisję $\mathrm{NO}_{x}$ [20]. Jednak istnieje kilka teoretycznych powodów do obniżenia emisji NO przed reaktorem katalitycznym wraz ze wzrostem zawartości etanolu w benzynie [23]. Należą do nich: szybsze spalanie (ze względu na większą szybkość rozprzestrzeniania się płomienia w etanolu w porównaniu do benzyny $[6,10$, 24]), większa absorpcja ciepła w cylindrze (ze względu na wyższe utajone ciepło parowania etanolu, w porównaniu do benzyny [25]), niższa temperatura płomienia [26] oraz ogólny efekt zubażania związany z zawartością tlenu w etanolu [10] (większą o ok. 34\% niż dla standardowej benzyny). W świetle przedstawionych wyżej czynników, jakikolwiek wzrost emisji $\mathrm{NO}_{x}$ w gazach wylotowych, w normalnych warunkach pracy może być spowodowany zmniejszeniem skuteczności TWC, ze względu na stosowanie uboższych mieszanin.

Niska proporcja $\mathrm{C}: \mathrm{H}$ w etanolu mogłaby sugerować zmniejszenie emisji $\mathrm{CO}_{2} \mathrm{w}$ gazach wylotowych silnika. Jednak wzrost sprawności spalania prowadzi do zmniejszenia emisji $\mathrm{HC}$ i CO, ale zwiększa się emisja $\mathrm{CO}_{2}$. Dodatkowo niższa wartość opałowa etanolu zwykle wymaga zwiększenia dawki paliwa [5 - 7, 17 - 19], zwiększając tym samym w niewielkim stopniu emisję $\mathrm{CO}_{2}$. Całkowity bilans emisji $\mathrm{CO}_{2}$ pochodzący ze spalania etanolu zależy w znacznym stopniu od sposobu jego produkcji $[7,19]$.

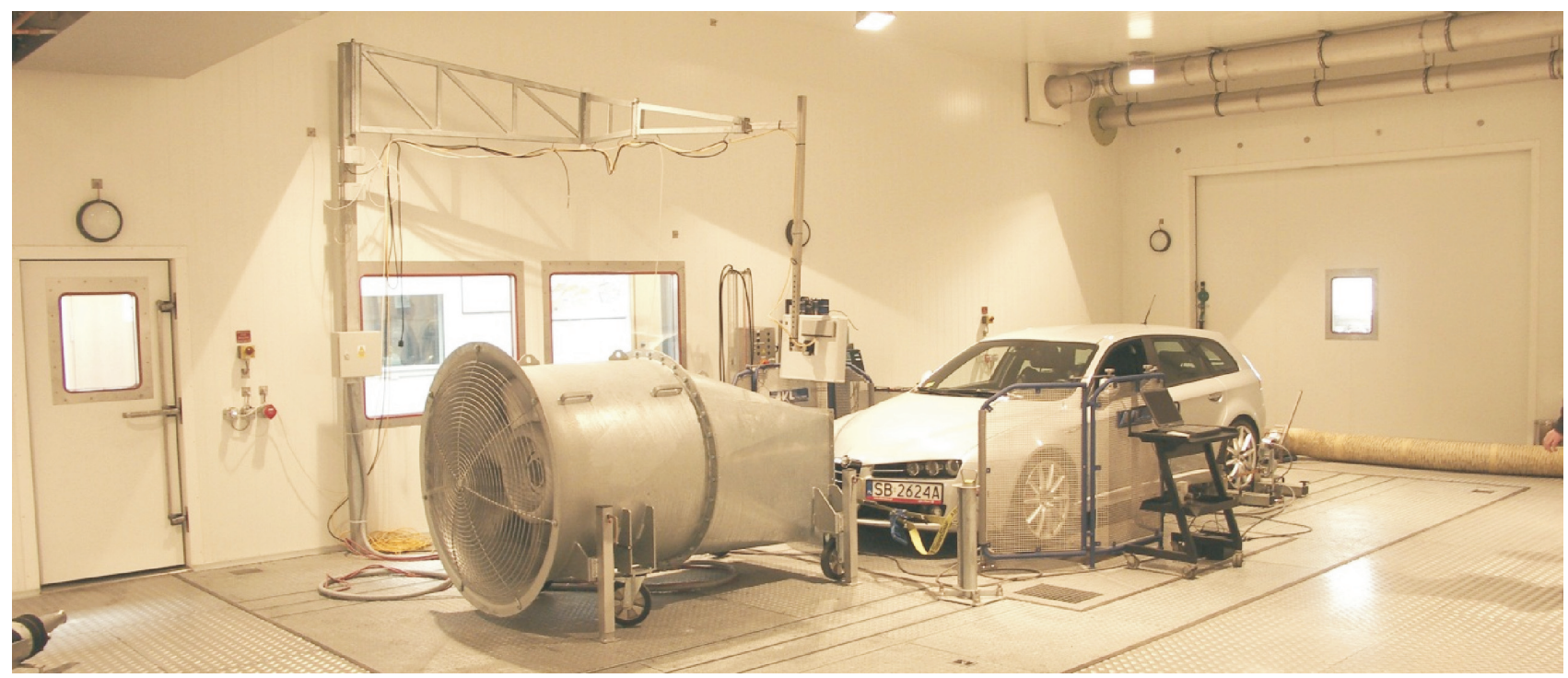

Fig. 1. Exhaust emissions laboratory at BOSMAL, showing the chassis dynamometer, windspeed fan and a vehicle, all within the climatic chamber Rys. 1. Laboratorium emisji spalin BOSMAL - hamownia podwoziowa, wentylator oraz zamontowany samochód, umieszczonych w komorze klimatycznej 
The test vehicle used for all work described here was a Euro 5 passenger car, with characteristics as shown in Table 1. The calibration of the engine control unit (ECU) was not altered in any way. Thermocouples were installed in the inlet port of the three-way catalyst (TWC) and on the emissions sampling line just downstream of the tailpipe, to obtain preand post-catalyst temperature data. Fuel consumption data were calculated using the carbon balance method, whose variables were modified according to the density and carbon weight fraction of the various fuel blends.

Table 1. Characteristics of the test vehicle used

Tabela 1. Parametry silnika samochodu badawczego

\begin{tabular}{|l|c|}
\hline Ignition type/rodzaj zapłonu & Spark ignition/zapł. iskrowy \\
\hline Number of cylinders/liczba cylindrów & 4 \\
\hline Number of valves/liczba zaworów & 8 \\
\hline Displacement/poj. silnika & Approx./ok. $1.3 \mathrm{dm}^{3}$ \\
\hline $\begin{array}{l}\text { Aftertreatment System/układ } \\
\text { oczyszczania spalin }\end{array}$ & $\begin{array}{c}\text { Close-coupled/reaktor } \\
\text { trójfunkcyjny TWC }\end{array}$ \\
\hline Emissions standard/standard emisji & Euro 5 \\
\hline
\end{tabular}

The vehicle was tested over the New European Driving Cycle (NEDC) [27] (Fig. 2). This widely-used cycle features a cold start and both urban and extra-urban driving conditions, covering a total distance of approximately $11 \mathrm{~km}$. The same driving cycle was also used to pre-condition the vehicle after switching from one fuel blend to the next.

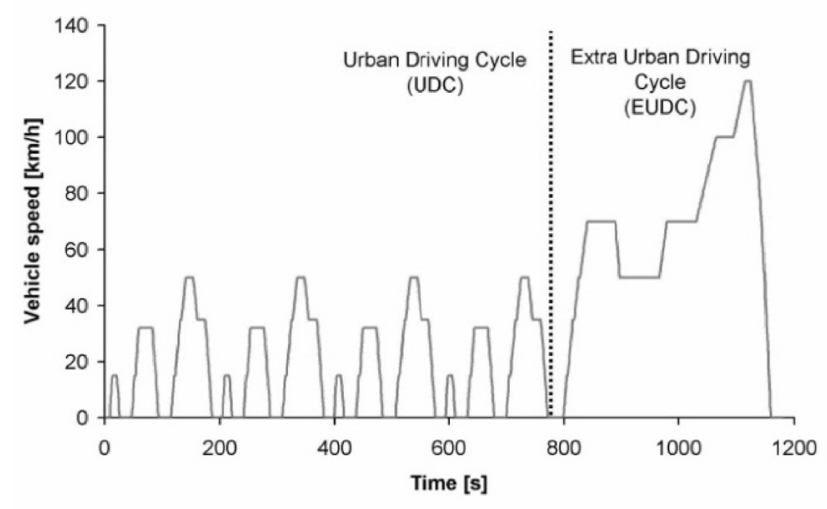

Fig. 2. The New European Driving Cycle (NEDC)

Rys. 2. Nowy Europejski Cykl Jezdny (NEDC)

\section{Results}

\subsection{Exhaust emission}

The results and discussion that follow refer to the mean value obtained from two to three tests performed on each fuel blend. All emission results are presented in comparison to the E5 blend. The results are shown graphically in the figures below as percentages.

As shown in Fig. 3, a gradual decrease in $\mathrm{HC}$ emissions was observed as the blend ethanol content increased from $5 \%$ to $50 \%$. Usage of the E85 blend caused substantial excess emission of hydrocarbons during the UDC, but low

\section{Metodyka badań własnych}

Badania w zakresie analizy poziomu emisji związków szkodliwych w spalinach przeprowadzono na pięciu różnych mieszankach paliw na samochodzie spełniającym normy emisji Euro 5, bez zmian w kalibracji układu sterowania silnikiem (ECU). Dla każdej mieszanki wykonano od dwóch do trzech testów emisji. Ponieważ wszystkie sprzedawane benzyny na Polskim rynku zawierają 5\% dodatku etanolu (E5) (objętościowo), z tego powodu paliwo to posłużyło jako paliwo referencyjne podczas badań.

Wszystkie prace eksperymentalne opisane w niniejszym artykule wykonano w laboratorium emisji spalin Euro 5/6 Zakładu Badań Silników IBiRM BOSMAL, które umożliwia wykonywanie kompleksowej analizy emisji związków szkodliwych i toksycznych w spalinach samochodowych w kontrolowanych warunkach otoczenia (wilgotność, temperatura). Laboratorium wyposażone jest w komorę klimatyczną, wewnątrz której znajduje się jednorolkowa hamownia podwoziowa oraz wentylator symulujący prędkość wiatru w czasie jazdy samochodu podczas testu emisji (rys. 1).

Wszystkie przeprowadzone i opisane w niniejszym artykule badania wykonano na samochodzie osobowym spełniającym wymagania norm emisji Euro 5, którego dane przedstawiono w tabeli 1. Kalibracja elektronicznego modułu sterującego pracą silnika (ECU) nie była w żaden sposób modyfikowana.

Czujniki temperatur zamontowano w układzie wylotowym silnika w miejscu wlotu do reaktora katalitycznego (pomiar spalin surowych z silnika) oraz w miejscu wylotu z reaktora (rura wylotowa samochodu), w celu uzyskania wartości temperatur przed i za reaktorem TWC. Zużycie paliwa było obliczone metodą bilansu węgla, którego zmienne były modyfikowane w zależności od gęstości i wagowego udziału węgla $\mathrm{w}$ różnych mieszankach benzyny z etanolem.

Badania wykonano na podstawie testu jezdnego NEDC [27] (rys. 2). Test ten obejmuje zimny rozruch silnika oraz cykl jazdy w warunkach miejskich i pozamiejskich o łącznym dystansie około $11 \mathrm{~km}$. Ten sam test jezdny wykorzystywany był w celu kondycjonowania pojazdu i układu zasilania po zmianie mieszanki paliwa na kolejne.

\section{Wyniki badań}

\subsection{Emisja związków szkodliwych spalin}

Przedstawione w niniejszym artykule wyniki odnoszą się do wartości średniej uzyskanej z dwóch lub trzech testów emisji wykonanych na każdej mieszance paliw. Wszystkie prezentowane wyniki są porównywane do mieszanki E5. Procentowe wyniki przedstawiono graficznie na rysunkach poniżej.

Jak pokazano na rysunku 3, stopniowy spadek emisji HC zaobserwowano dla mieszanek o zawartości etanolu wzrastającej z 5\% do 50\%. Zastosowanie mieszanki E85 spowodowało z jednej strony znaczny wzrost emisji węglowodorów w fazie UDC, ale z drugiej strony niski poziom emisji w fazie EUDC. W całym teście NEDC mieszanki E10, E25 i E50 wykazały tendencję do obniżenia emisji $\mathrm{HC}$ w porównaniu ze standardowym paliwem E5. 
emissions during the extra-urban phase (EUDC). Over the entire NEDC, ethanol blends E10, E25 and E50 produced lower HC emissions than the standard E5 blend.

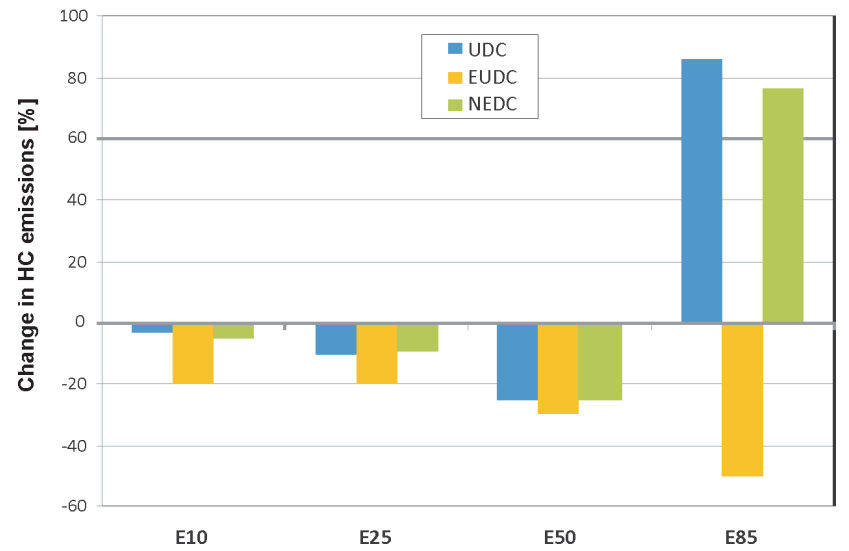

Fig. 3. Change in HC emissions for blends E10-E85 over the NEDC in comparison to the $\mathrm{E} 5$ blend

Rys. 3. Zmiana emisji HC w teście NEDC dla mieszanek E10-E85 w porównaniu z mieszanka E5

Emissions of the other main product of partial combustion, carbon monoxide, were generally lower for ethanol blends E10-E50 (Fig. 4), with two exceptions during the EUDC for blends E10 and E25. The E85 blend was observed to cause higher emissions than E5 during the UDC, but much lower emissions during the EUDC. Significantly, over the entire NEDC, all blends tested outperformed the standard E5 blend in terms of $\mathrm{CO}$ emission, with E50 offering the most substantial reduction.

Emissions of $\mathrm{NO}_{\mathrm{x}}$, shown in Fig. 5, were observed to be similar for blends E10 and E25, with both outperforming E5 during the UDC, and the NEDC. Blends E50 and E85 caused higher emissions, particularly during the EUDC. A rapid increase of $\mathrm{NO}_{x}$ emission during the EUDC was observed for increasing blend ethanol content. Over the NEDC, results revealed a monotonic increase in $\mathrm{NO}_{\mathrm{x}}$ emissions over the range $10 \%$ to $85 \%$ ethanol content.

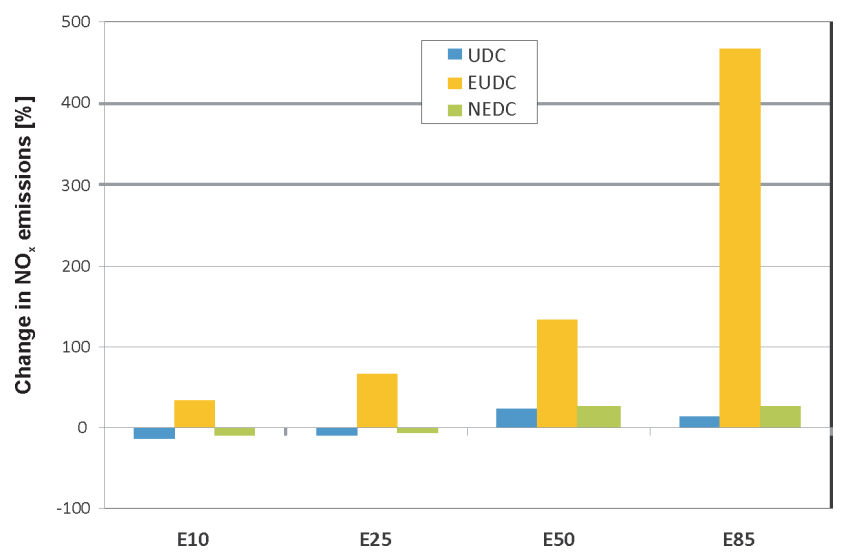

Fig. 5. Change in $\mathrm{NO}_{\mathrm{x}}$ emissions for blends E10-E85 over the NEDC in comparison to blend $\mathrm{E} 5$

Rys. 5. Zmiana emisji $N_{x}$ w teście NEDC dla mieszanek E10-E85 w porównaniu do mieszanki E5
Poziom emisji drugiego z głównych produktów niezupełnego spalania, tlenku węgla (CO), był na ogół niższy dla mieszanek E10, E25 i E50 (rys. 4). Wyjątkiem były dwa

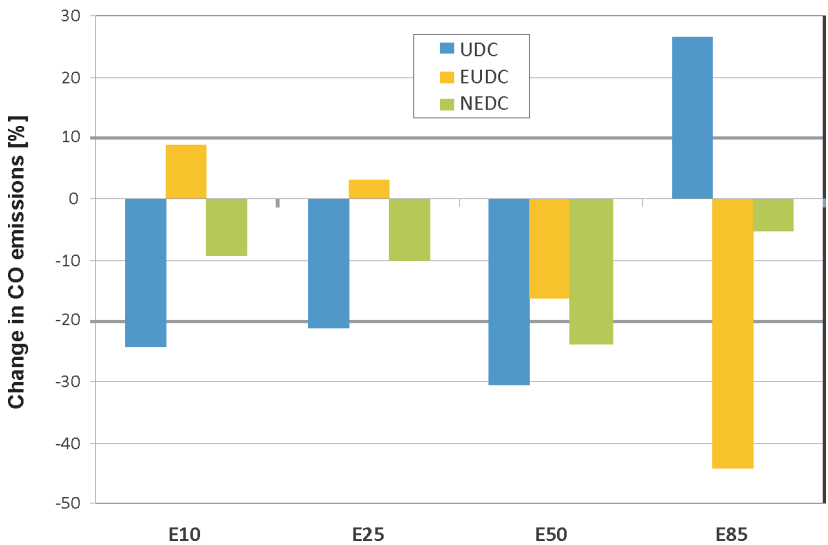

Fig. 4. Change in CO emissions for blends E10-E85 over the NEDC in comparison to blend $\mathrm{E} 5$

Rys. 4. Zmiana emisji CO w teście NEDC dla mieszanek E10-E85 w porównaniu do mieszanki E5

przypadki uzyskane w fazie EUDC dla mieszanek E10 i E25. Dla mieszanki E85 zaobserwowano zwiększenie emisji w porównaniu do mieszanki E5 podczas fazy UDC, ale znacznie niższą emisję podczas fazy EUDC. W całym teście NEDC, na wszystkich testowanych mieszankach, uzyskano lepsze wyniki pod względem emisji $\mathrm{CO}$ w porównaniu do standardowej mieszanki E5. Ponadto na mieszance E50 uzyskano znaczące zmniejszenie emisji CO.

Uzyskane wyniki emisji NO przedstawiono na rysunku 5. Poziom emisji dla mieszanek E10 i E25 był podobny; obie mieszanki w porównaniu do paliwa odniesienia E5 wykazują niższą emisję w fazie UDC i w teście NEDC. Dla mieszanek E50 i E85 zaobserwowano wzrost emisji $\mathrm{NO}_{\mathrm{x}}$, szczególnie podczas fazy EUDC. Szybki wzrost emisji $\mathrm{NO}_{\mathrm{x}} \mathrm{w}$ fazie EUDC obserwowano wraz ze zwiększeniem zawartości etanolu w mieszaninie. Podczas testu NEDC, otrzymane

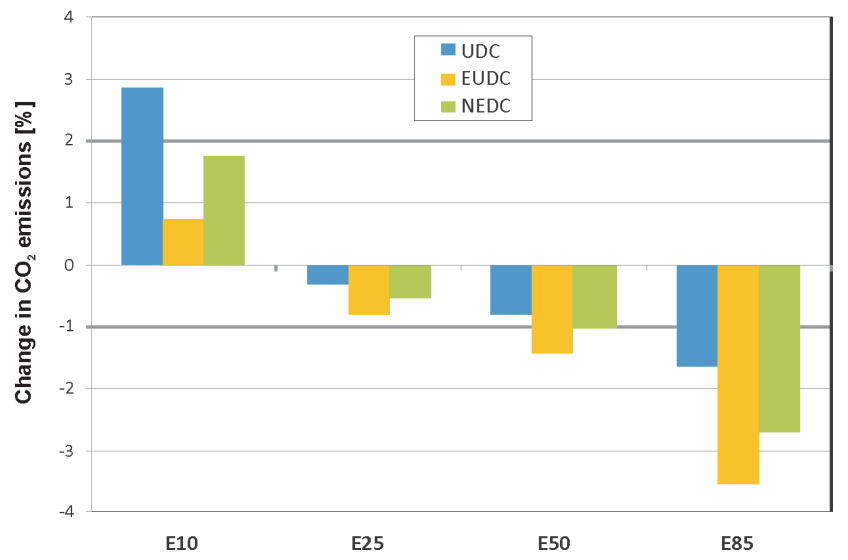

Fig.6. Change in $\mathrm{CO}_{2}$ emissions for blends E10-E85 over the NEDC in comparison to blend $\mathrm{E} 5$

Rys.6. Zmiana emisji $\mathrm{CO}_{2}$ w teście NEDC dla mieszanek E10-E85 w porównaniu do mieszanki E5 
The $\mathrm{CO}_{2}$ emissions response showed relatively little variation from one blend to the next, as shown in Fig. 6. During both phases, $\mathrm{CO}_{2}$ emissions showed a slight increase for the E10 blend, compared to E5. Over the range $10-85 \%$ ethanol content, a very gradual downwards trend was observed for both phases of the test cycle. The only blend containing more ethanol than petrol - E85 - emitted approximately $2.7 \%$ less $\mathrm{CO}_{2}$ over the entire NEDC than the E5 blend. Mean results for blends E10, E25 and E50 were all within 2\% of the mean result for the E5 blend.

\subsection{Fuel consumption}

Calculated fuel consumption over the entire NEDC increased for blends E10, E25, E50 and E85, when compared to E5 (Fig. 7), which appears simply to be a reflection of

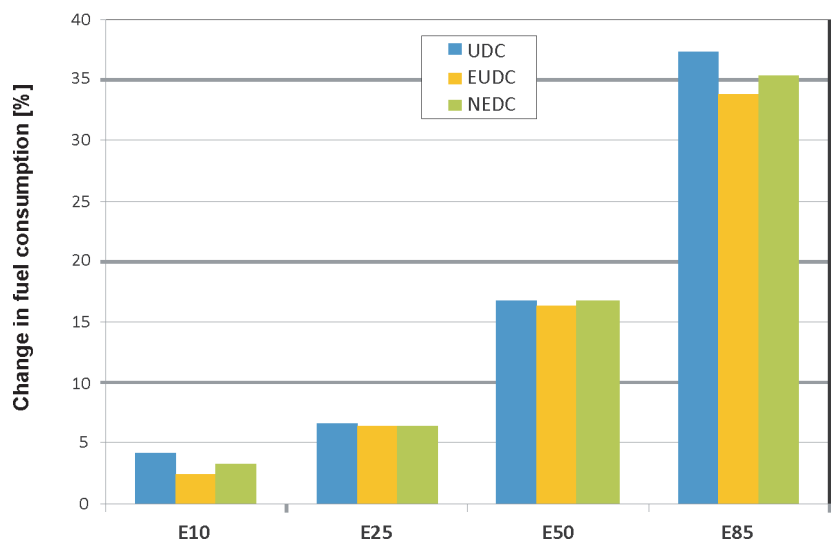

Fig. 7. Change in fuel consumption for blends E10-E85 over the NEDC in comparison to blend $\mathrm{E} 5$

Rys.7. Zmiana zużycia paliwa w teście NEDC dla mieszanek E10-E85 w porównaniu do mieszanki E5

the reduced energetic content of ethanol compared to petrol. Consumption of the E85 blended fuel appeared to have increased further than could be accounted for by the lower energetic content of this blend.

The lower energetic content of ethanol compared to petrol is an inherent disadvantage of ethanol as a fuel. However, the high anti-knock index (AKI) of ethanol permits the use of higher compression ratios, which could compensate somewhat for the reduced energetic content of mid-to-high ethanol blends [28]. Such a strategy would, however, require modifications to both the engine and the TWC.

\subsection{Air fuel ratio $(\lambda)$}

The air:fuel ratio (lambda $\lambda$ ) was found to vary with the blend, as shown in Fig. 8. For blends E5, E10 and E25 the percentage of time spent in lean operation $(\lambda>1)$ did not vary significantly, with a values in the range $35 \%$ to $39 \%$; the E50 blend caused the engine to operate lean some $53 \%$ of the time. The E85 blend caused lean operation during $81 \%$ of the NEDC, with lean conditions occurring under a variety of driving conditions. wyniki charakteryzowały się monotonicznym wzrostem emisji $\mathrm{NO}_{\mathrm{x}} \mathrm{w}$ przedziale zawartości alkoholu etylowego od $10 \%$ do $85 \%$.

Uzyskane wyniki emisji $\mathrm{CO}_{2}$ wykazały stosunkowo niewielki wpływ zawartości etanolu na emisję tego związku, co przedstawiono na rys. 6. Podczas obu faz (UDC i EUDC) emisja $\mathrm{CO}_{2}$ nieznacznie wzrosła dla mieszanki E10, w porównaniu do E5. W zakresie zmiany zawartości etanolu od 10\% do $85 \%$ zaobserwowano bardzo stopniowy spadek emisji $\mathrm{CO}_{2}$ w obu fazach testu. Dla mieszanki zawierającej więcej etanolu niż benzyny (E85) emisja była około 2,7\% mniejsza w całym teście NEDC w porównaniu do mieszanki referencyjnej E5. Średnie wyniki dla mieszanek E10, E25 i E50 były w granicach 2\% średniego wyniku dla mieszanki E5.

\subsection{Zużycie paliwa}

Obliczone zużycie paliwa w całym teście NEDC wzrosło dla mieszanek E10, E25, E50 i E85, w porównaniu do mieszaniny E5 (rys. 7), co wynika ze zmniejszonej wartości opałowej tych mieszanin w porównaniu do benzyny. Zużycie paliwa uzyskane na mieszance E85 wzrosło bardziej niż się spodziewano, w odniesieniu do jej niższej wartości opałowej.

Niższa zawartość energetyczna etanolu w porównaniu do benzyny jest jego wadą w kontekście zastosowania etanolu jako paliwa do napędu pojazdów. Jednak wysoki indeks przeciwstukowy (AKI) etanolu pozwala na użycie wysokich stopni sprężania, co może rekompensować nieco obniżoną zawartość energetyczną mieszanek o średniej i dużej zawartości etanolu w mieszaninie [28], ale taka strategia wymaga modyfikacji zarówno silnika, jak i zastosowania specjalnego reaktora katalitycznego.

\subsection{Współczynnik nadmiaru powietrza $(\lambda)$}

Podczas przeprowadzonych badań stwierdzono różnice w wartościach współczynnika nadmiaru powietrza w zależności od składu mieszanki, co przedstawiono na rysunku 8. Dla mieszanek E5, E10 i E25 procent czasu pracy silnika na mieszance ubogiej $(\lambda>1)$ nie różnił się

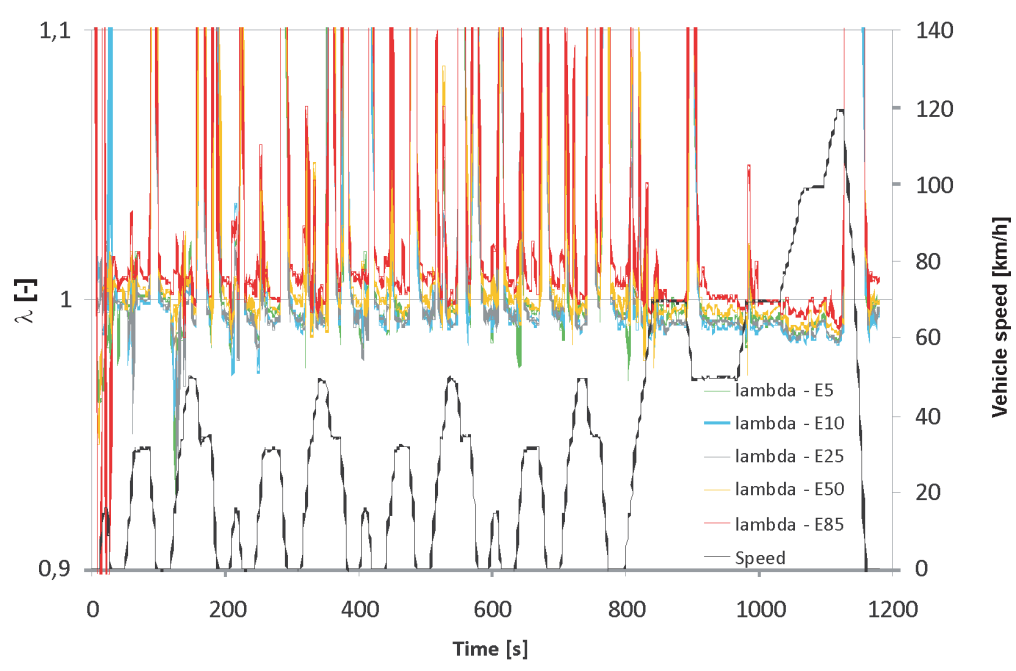

Fig. 8. Lambda values within the range $0.9-1.1$ for all blends tested Rys. 8. Wartość wspótczynnika nadmiaru powietrza w zakresie 0,9-1,1 dla wszystkich testowanych mieszanek 


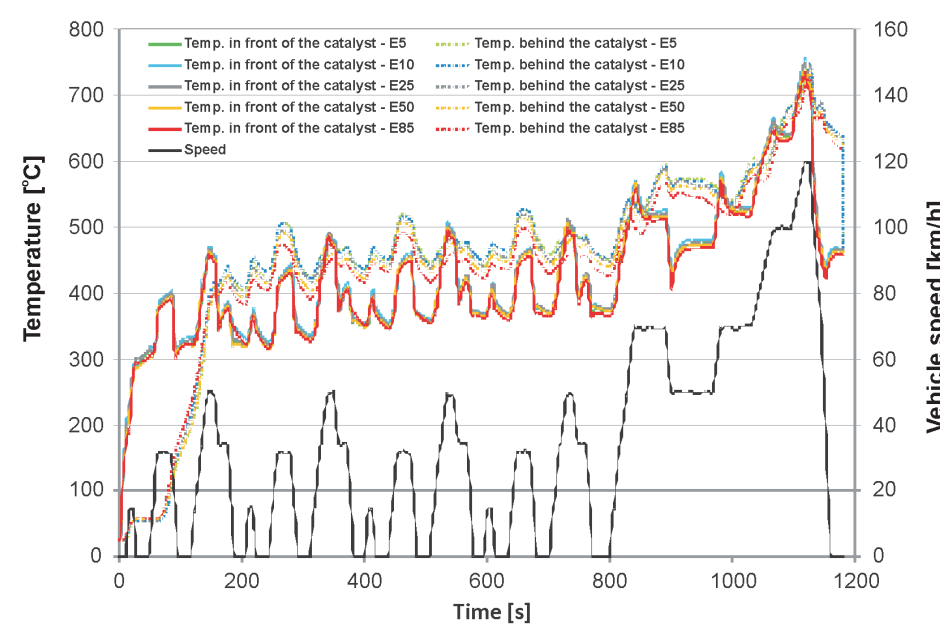

Fig. 9. Pre- and post-catalyst temperature traces over the NEDC for blends E5-E85 Rys. 9. Zmiany temperatury przed i za reaktorem katalitycznym $w$ teście NEDC dla mieszanin benzyny z etanolem E5-E85

\subsection{Exhaust temperature}

Pre-catalyst temperature data were also found to vary according to the blend in use, as shown in Fig. 9. The lowest engine out temperatures were observed when the vehicle was running on the E85 blend.

\section{Discussion}

Exhaust emissions from blends E10 and E25 were generally acceptable. The E50 and E85 blends showed excess $\mathrm{NO}_{x}$ emissions, while the E85 blend was also problematic in terms of startup and exhaust emissions of $\mathrm{HC}$. The reduction in tailpipe emissions of $\mathrm{NO}_{\mathrm{x}}$ for blends E10 and E25 is significant, and is in agreement with some other studies [7, 9]. The high oxygen content of blends E50 and E85, and the lean operation this caused, was probably a contributing factor to high $\mathrm{NO}_{x}$ emissions from these blends, as the TWC's $\mathrm{NO}_{x}$ reduction efficiency would have been lower. The standard engine calibration used in the unmodified vehicle was evidently not suitable for these higher blends, E85 in particular. Other effects, such as problems with fuel delivery, may also have contributed. A general trend in emission results was that the emissions response to increasing blend ethanol content is not always linear. For a particular pollutant, an optimum level of ethanol content may exist - and emissions will be higher both above and below this point, as was the case for emissions of $\mathrm{HC}, \mathrm{CO}$ and $\mathrm{NO}_{\mathrm{x}}$ over the NEDC. The change in TWC light-off temperature for $\mathrm{HC}, \mathrm{CO}$ or $\mathrm{NO}_{x}$ varies both with the precious metal, and the blend's ethanol content [30]. Increased ethanol content appears to raise light-off temperatures in many cases [30]. Non-linearity in tailpipe emissions responses may be due to a complex trade-off between lower engine out emissions, slight delays in reaching TWC light-off temperature, and variations in the effectiveness of the TWC in response to the chemistry of the exhaust gas. As the TWC fitted to the vehicle used in this study was not designed for use with ethanol blends, it is not unexpected that higher ethanol blends were observed to cause emissions excesses [9]. The observed increase in fuel consumption, occurring znacznie i zawierał się w zakresie od 35\% do 39\% czasu trwania testu NEDC; na mieszance E50 czas ten wynosił około 53\%. Dla mieszanki E85 praca silnika na mieszance ubogiej stanowiła $81 \%$ czasu trwania testu NEDC, również zakres pracy silnika cechowała różnorodność warunków występowania takiej mieszanki.

\subsection{Przebiegi temperatur spalin}

Stwierdzono wyraźne różnice w przebiegu zmian temperatur przed reaktorem katalitycznym w zależności od mieszanki użytej do badań (rys. 9). Najniższe wartości temperatur spalin zmierzono podczas pracy silnika na mieszance E85.

\section{Analiza wyników badań}

Emisja związków szkodliwych spalin przy zastosowaniu mieszanek E10 i E25 kształtowała się na akceptowalnym poziomie nieodbiegającym od emisji uzyskanej przy stosowaniu paliwa odniesienia (E5). Wyższy poziom emisji $\mathrm{NO}_{\mathrm{x}}$ uzyskano na mieszance E50 i E85, natomiast na mieszance E85 zaobserwowano również problemy $\mathrm{w}$ rozruchu silnika oraz wzrost emisji HC. Obniżenie emisji $\mathrm{NO}_{x}$ dla mieszanek E10 i E25 jest znaczne i zgodne z innymi badaniami eksperymentalnymi [7, 9]. Duża zawartości tlenu w mieszankach paliwa E50 i E85, prowadząca do pracy silnika w zakresie mieszanki ubogiej, była prawdopodobnie w tych przypadkach przyczyną wysokiej emisji $\mathrm{NO}_{\mathrm{x}}$ oraz obniżonej sprawności redukcji tlenków azotu w reaktorze katalitycznym. Standardowa kalibracja ECU silnika, w którą był wyposażony badany samochód, jednoznacznie okazała się niewłaściwą $\mathrm{w}$ zastosowaniu $\mathrm{z}$ mieszankami o dużej zawartości etanolu, szczególnie mieszanki E85. Inne problemy, takie jak np. z układem zasilania mogą również przyczyniać się do zwiększonej emisji $\mathrm{NO}_{x}$. Ogólną tendencją zaobserwowaną podczas badań jest zmieniająca się nieliniowo emisja związków szkodliwych wraz ze wzrostem zawartości etanolu w mieszance. W przypadku emisji $\mathrm{HC}, \mathrm{CO}$ i NO podczas testu NEDC istnieje optymalny poziom zawartości etanolu, dla którego emisja kształtuje się powyżej oraz poniżej tego optimum. Zmiana temperatury „light-off” TWC dla HC, CO i NO zależy zarówno od metali szlachetnych zastosowanych w reaktorze, jak i od zawartości etanolu w mieszance [30]. Większa zawartość etanolu, w wielu przypadkach, powoduje wzrost temperatury „lightoff" reaktora katalitycznego [30]. Nieliniowe zachowanie emisji związków szkodliwych może być spowodowane złożonym kompromisem pomiędzy niższą emisją gazów wylotowych z silnika, niewielkim opóźnieniem w uzyskaniu temperatury ,light-off” w TWC i zmianą skuteczności odpowiedzi TWC na skład chemiczny spalin. Używany reaktor katalityczny w badanym pojeździe nie został zaprojektowany do stosowania z paliwami z dodatkiem etanolu, dlatego nie jest zaskoczeniem, że dla mieszanek z większą zawartością etanolu zaobserwowano nadmierną emisję [9]. Liniowy wzrost zużycia paliwa dowiódł, że istnieje wpływ mniejszej zawartość energetycznej etanolu na ten parametr i ma on duże znaczenie. 
as a response to the lower energetic content of ethanol, is of significance.

\section{Conclusions and summary}

The results presented above underline the viability of using low petrol-ethanol blends in modern passenger cars, as far as regulated exhaust emissions are concerned. Tailpipe emission data presented here suggest that modest improvements in air quality would result from usage of low-to-mid ethanol blends in the vehicle tested. In consideration of the results and analyses presented above, it has been possible to determine that the unmodified Euro 5 vehicle used in this study could be operated on various petrol-ethanol blends, from E5 to E50, but E85 performed very poorly - cold start was problematic, the mixture was generally very lean, fuel consumption was high, and emissions of $\mathrm{HC}$ and $\mathrm{NO}_{x}$ were substantially higher. In order to better understand the processes and effects leading to changes in emission levels when running on higher petrol-ethanol blends, it would be advantageous to conduct tests on a vehicle with an altered calibration tailored towards usage of richer ethanol-petrol blends. While ethanol shows promise as a potential candidate for partial replacement of fossil fuels, this study has highlighted the continued need for further detailed research into the emissions costs and benefits of using blends higher than E5 in unmodified vehicles. Blends E10 and E25 have been shown to perform well on the vehicle tested in this study. While this study has focused on exhaust emissions and fuel consumption, further work on reliability, component durability and aftertreatment system compatibility is required. In order to have sufficient information to make sound engineering, commercial and political decisions, wide-ranging test programmes on low-to-mid ethanol blends in standard passenger cars are required.

\section{Acknowledgment}

Support for this research project was provided by the Polish Ministry of Science and Higher Education from research funds 2010-2012: Grant N N509 494838

Paper reviewed/Artykut recenzowany

\section{Wnioski i podsumowanie}

Przedstawione wyżej wyniki potwierdzają możliwość stosowania mieszanek o małej zawartości etanolu w benzynie, w nowoczesnych pojazdach, pod warunkiem spełnienia limitów emisji spalin. Uzyskane wyniki pokazują umiarkowaną obniżkę zawartości związków szkodliwych w spalinach przy zastosowaniu niskich i średnich stężeń etanolu w mieszankach z benzyną, w badanym samochodzie. Na podstawie uzyskanych wyników i przedstawionej analizy udało się ustalić, że pojazd spełniający normy emisji Euro 5, przy jednoczesnym braku ingerencji w kalibrację elektronicznej jednostki sterującej pracą silnika, może być zasilany mieszankami o różnej zawartości etanolu w mieszaninie, od E5 do E50, ale dla mieszaniny E85 osiągi silnika są gorsze - pojawiają się problemy z rozruchem silnika na zimno, występuje spalanie mieszanek ubogich, wzrasta zużycie paliwa oraz znacznie wzrasta emisja $\mathrm{HC}$ i NO . W celu lepszego zrozumienia procesów i efektów zmian poziomu emisji podczas pracy na mieszankach o większej zawartości etanolu w benzynie, korzystne byłoby przeprowadzenie testów w pojeździe wyposażonym w silnik o zmodyfikowanej kalibracji, dostosowanej do mieszanek bogatszych w etanol. Chociaż etanol wykazuje pozytywne cechy w zastosowaniu jako paliwo silnikowe, częściowo mogące zastąpić obecnie stosowane paliwa kopalne, badania wykazały potrzebę dalszych, szczegółowych prac nad kosztami obniżenia emisji i korzyściami wynikającymi z zastosowania mieszanek innych niż E5 w pojeździe wyposażonym w standardową kalibrację ECU. Badania na mieszankach E10 i E25 wykazały, że mieszanki te charakteryzują się dobrymi właściwościami i osiągami uzyskanymi na badanym pojeździe. Przeprowadzone badania koncentrowały się na określeniu emisji składników toksycznych spalin i zużyciu paliwa, ale niezbędne są dalsze prace nad niezawodnością, trwałością i zgodnością układów oczyszczania spalin montowanych w układach wylotowych pojazdów. W celu uzyskania wystarczających informacji dla podjęcia właściwych inżynieryjnych, handlowych i politycznych decyzji wymagane są obszerne programy badawcze na temat zastosowania mieszanek o niskiej i średniej zawartości etanolu do standardowych samochodów osobowych.

\section{Podziękowanie}

Badania zostały wykonane w ramach projektu badawczego nr NN 509494838 finansowanego przez Ministerstwo Nauki i Szkolnictwa Wyższego na lata 2010-2012.

\section{Nomenclature/Skróty i oznaczenia}

$\lambda \quad$ Lambda/wspótczynnik nadmiaru powietrza

$\mathrm{CO}$ Carbon monoxide/tlenek węgla

$\mathrm{CO}_{2}$ Carbon dioxide/dwutlenek węla

E5 Fuel blend with 5\% ethanol content/mieszanka paliwa $z$ 5-procentowa zawartościa etanolu

ECU Engine Control Unit/Elektroniczna Jednostka Sterujaca

Ex Fuel blend with $\mathrm{x} \%$ ethanol content/mieszanka paliwa $z$ $x \%$ zawartościa etanolu

EUDC Extra Urban Driving Cycle/Pozamiejski Cykl Jezdny

HC Hydrocarbons/węglowodory

MON Motor octane number/motorowa liczba oktanowa

NEDC New European Driving Cycle/Nowy Europejski Test Jezdny

$\mathrm{NO}_{\mathrm{x}}$ Oxides of nitrogen/tlenki azotu

RON Research octane number/badawcza liczba oktanowa

ZI Spark ignition/zapton iskrowy

TWC Three-way catalyst/trójfunkcyjny reaktor katalityczny

UDC Urban Driving Cycle/Miejski Cykl Jezdny

v Volume/objętość

$\varepsilon \quad$ Compression ratio/stopień kompresji 


\section{Bibliography/Literatura}

[1] Goldemburg J.: Ethanol for a Sustainable Energy Future. Science, 315, 5813, 808-810, 2007.

[2] Demirbas A.: Emission Characteristics of Gasohol and Diesohol. Energy Sources, Part A, 31,1099-1104, 2009.

[3] Directive 2009/30/EC of the European Parliament and of the Council of 23 April 2009. Official Journal of the European Union, 5.6.2009, L140, 88-113.

[4] Partial Grant and Partial Denial of Clean Air Act Waiver Application. EPA document EPA-HQ-OAR-2009-0211, 2011.

[5] Eyidogan M. et al.: Impact of alcohol-gasoline fuel blends on the performance and combustion characteristics of an SI engine. Fuel, 89, 2713-2720, 2010.

[6] Negurescu N. et al.: Aspects of Using Ethanol in SI Engines. FISITA paper F2006P294, 2006.

[7] Niven R.K.: Ethanol in gasoline: environmental impacts and sustainability review. Renewable and Sustainable Energy Reviews, 9, 535-555, 2005.

[8] Intensive Field Trial of Ethanol/Petrol Blend in Vehicles, Energy Research \& Development Corporation Project No. 2511, 1998.

[9] Bielaczyc P., Szczotka A., Wojnarowicz M.: The alternative fuels powertrain technology evolution. Polish Society of Combustion Engines paper PTNSS-2009-SC-162, 2009.

[10] Bayraktar H.: Experimental and theoretical investigation of using gasoline-ethanol blends in spark-ignition engines. Renewable Energy, 30, 1733-1747, 2005.

[11] Ertekin A., Sridhar N.: Performance of Elastomeric Materials in Gasoline - Ethanol Blends - A Review. NACE 2009 Corrosion Conference and Expo, 2009.

[12] Ambrozin A.R.P., Kuri S.E.: Corrosão Metálica Associada ao Uso de Combustíveis Minerais e Biocombustíveis. Quim. Nova, Vol. 32, No. 7, 1910-1916, 2009.

[13] Technical Assessment of the Feasibility of Introducing E15 Blended Fuel in U.S. Vehicle Fleet, 1994 to 2000 Model Years. Ricardo project FE405, 2010.

[14] Bielaczyc P., Szczotka A., Woodburn J.: The Impact of Different Petrol-Ethanol Blends on the Exhaust Emissions from a Modern Light-Duty Petrol Engine. EAEC2011_0194, 13th EAEC European Automotive Congress, Valencia 2011.

[15] Bielaczyc P., Szczotka A., Woodburn J.: The Effect of Various Petrol-ethanol Blends on Exhaust Emissions and Fuel Consumption of an Unmodified Light-Duty SI Vehicle. SAE Paper 2011-24-0177, ICE2011 - 10th International Conference on Engines \& Vehicles, Naples 2011.

Piotr Bielaczyc, DEng. - head of the Engine Research Department, BOSMAL Automotive Research and Development Institute Ltd in Bielsko-Biała.

Dr inż. Piotr Bielaczyc - kierownik Zakładu Badań Silników, Instytut Badań i Rozwoju Motoryzacji BOSMAL Sp. z o.o., Bielsko-Biala.

e-mail:piotr.bielaczyc@bosmal.com.pl

Andrzej Szczotka, DEng. - doctor in Engine Research Department at the BOSMAL Automotive Research \& Development Institute Ltd in Bielsko-Biała.

Dr inż. Andrzej Szczotka - adiunkt w Zakladzie Badań Silników Instytut Badań i Rozwoju Motoryzacji BOSMAL Sp. z o.o., Bielsko-Biata.

e-mail:andrzej.szczotka@bosmal.com.pl
[16] Bielaczyc P., Szczotka A., Woodburn J.: A Study of Gasoline-Ethanol Blends Influence on Performance and Exhaust Emissions from a Light-Duty Gasoline Engine. SAE Paper 2012-01-1052, SAE 2012 World Congress, Detroit, USA 2012.

[17] Bergstrom, K., Jones, C. The New Ecotech Turbo Biopower Engine from GM Powertrain. EAEC paper, 2009.

[18] Durbin T.D. et al.: Effects of Ethanol and Volatility Parameters on Exhaust Emissions. CRC Project No. E-67, 2006.

[19] Dias de Oliveira M.E. et al.: Ethanol as Fuel: Energy, Carbon Dioxide Balances, and Ecological Footprint. Bioscience, Vol. 55 No. 7, 2005.

[20] Hochhauser A.M.: Review of Prior Studies of Fuel Effects on Vehicle Emissions. SAE paper 2009-01-1181, 2009.

[21] Naidenko O.V.: Ethanol-Gasoline Fuel Blends May Cause Human Health Risks and Engine Issues. Environmental Working Group Review, 2009.

[22] Graham L.A. et al.: Emissions from light duty gasoline vehicles operating on low blend ethanol gasoline and E85. Atmospheric Environment, 42, 4498-4516, 2008.

[23] Review of fuel ethanol impacts on local air quality. Bioethanol for Sustainable Transport report No. D9.14, 2008.

[24] Yusaf T. et al.: Theoretical and experimental investigation of SI engine performance and exhaust emissions using ethanolgasoline blended fuels. 3rd International Conference on Energy and Environment (ICEE2009), 7-8 December 2009, Malacca, Malaysia.

[25] Agarwal A.K.: Biofuels (alcohols and biodiesel) applications as fuels for internal combustion engines. Progress in Energy and Combustion Science, 33, 233-271, 2007.

[26] Parag S. et al.: Emissions from ethanol blended fossil fuel flames. Experimental Thermal and Fluid Science, 35:1, 96104, 2011.

[27] Directive 98/69/EC of the European Parliament and of the Council of 13 October 1998. 1998L0069, 1998.

[28] Turner J.W.G. et al.: Alcohol-Based Fuels in High Performance Engines. SAE paper 2007-01-0056, 2007.

[29] Roberts M.C.: E85 and fuel efficiency: An empirical analysis of 2007 EPA test data. Energy Policy, Vol. 36, Issue 3, 1233$1235,2008$.

[30] Maununa T., Kinnenen T.: Effect of oxygen containing biofuels on the emissions with exhaust gas catalysts. SAE paper 200901-2737, 2009.

Dariusz Klimkiewicz, DEng. - doctor in the Engine Research Department, BOSMAL Automotive Research and Development Institute Ltd in Bielsko-Biała. Dr inż. Dariusz Klimkiewicz - adiunkt w Zaktadzie Badań Silników, Instytut Badań i Rozwoju Motoryzacji BOSMAL Sp. z o.o., Bielsko-Biała.

e-mail: dariusz.klimkiewicz@bosmal.com.pl

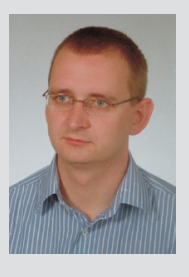

Joseph Woodburn, MSc. - researcher at the Engine Research Department, BOSMALAutomotive Research and Development Institute Ltd in Bielsko-Biała.

Mgr inż. Joseph Woodburn - inżynier ds. badań w Zakładzie Badań Silników, Instytut Badań i Rozwoju Motoryzacji BOSMAL Sp. z o.o., Bielsko-Biała. 